Document downloaded from:

http://hdl.handle.net/10251/157298

This paper must be cited as:

Caballer-Tarazona, V.; Guadalajara Olmeda, MN.; Vivas-Consuelo, D. (2019). Predicting healthcare expenditure by multimorbidity groups. Health Policy. 123(4):427-434. https://doi.org/10.1016/j.healthpol.2019.02.002

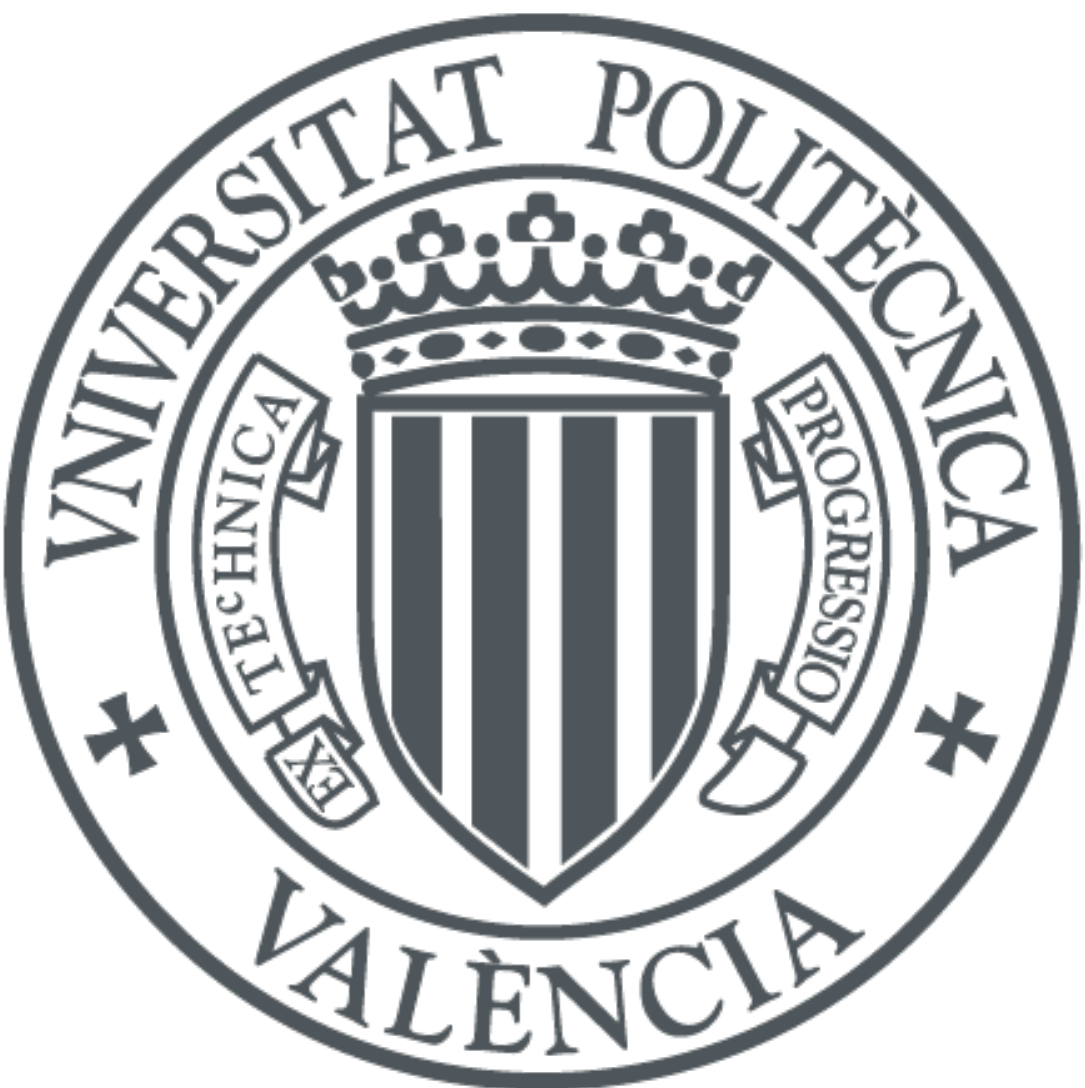

The final publication is available at

https://doi.org/10.1016/j.healthpol.2019.02.002

Copyright Elsevier

Additional Information 


\section{Predicting healthcare expenditure by multimorbidity groups}

Order of Authors: Vicent Caballer-Tarazona, PhD; Natividad Guadalajara-Olmeda, PhD; David Vivas-Consuelo, M.D., Ph.D.

Universitat Politècnica de València

2019

\section{Abstract \\ Objectives}

This article has two main purposes. Firstly, to model the integrated healthcare expenditure for the entire population of a health district in Spain, according to multimorbidity, using Clinical Risk Groups (CRG). Secondly, to show how the predictive model is applied to the allocation of health budgets.

\section{Methods}

The database used contains the information of 156,811 inhabitants in a Valencian Community health district in 2013. The variables were: age, sex, CRG's main health statuses, severity level, and healthcare expenditure. The two-part models were used or predicting healthcare expenditure. From the coefficients of the selected model, the relative weights of each group were calculated to set a case-mix in each health district.

\section{Results}

Models based on multimorbidity-related variables better explained integrated healthcare expenditure. In the first part of the two-part models, a logit model was used, while the positive costs were modelled with a $\log$-linear OLS regression. An adjusted $\mathrm{R}^{2}$ of $46-49 \%$ between actual and predicted values was obtained. With the weights obtained by CRG, the differences found with the case-mix of each health district proved most useful for budgetary purposes.

\section{Conclusions}

The expenditure models allowed improved budget allocations between health districts by taking into account morbidity, as opposed to budgeting based solely on population size.

Keywords: Budget; Case-mix system; Health econometrics; Healthcare expenditure; Multimorbidity; Risk adjustment; Two-part models. 


\section{Introduction}

The demographic change that the more developed countries, such as Spain, are undergoing and which is characterised by increased life expectancy and population ageing, is a major challenge that threatens the sustainability of both state health care systems and the welfare state. The main consequence of this new population configuration is the higher prevalence of chronic diseases, given the phenomenon of multimorbidity [1-3]. Together with the negative outcomes associated with multimorbidity, such as mortality, disability and deficient quality of life, we also see an increase in associated costs.

Predicting healthcare expenditure according to morbidity gives rise to two methodological questions: how to measure multimorbidity and which predictive models to choose. Regarding the former, a valid alternative is to use a risk adjustment system. Risk adjustment systems were developed to determine the multimorbidity profile and the population's general health status in order to establish capitation payment in medical service provision and better planning for health services. These systems are based on the diagnostics registered in electronic health databases and each individual is classified into a multimorbidity group. The most widely used patient classification systems for risk adjustments in health based on diagnostics are: Adjusted Clinical Groups (ACG) [4], Diagnostic Cost Groups (DCG) [5,6] and Clinical Risk Groups (CRG) [7].

CRGs have been applied to budgetary planning [8], to the comparison of health service utilization and expenditure between different risk groups $[9,10]$ and to the identification of high cost complex patients [11-14].

In this work, we use CRG as measure of multimorbidity. The CRG system classifies patients into different morbidity groups through disease codes from an electronic health record, using individual information on acute episodes and treatments for chronic conditions. From this information, each person is assigned to one of the 1,076 (depending on the version) CRGs. Each group is mutually exclusive and each individual is classified into categories with common clinical characteristics and similar consumption patterns. Moreover, each group can, in turn, be grouped into different aggregates as one of nine CRGs or mean health statuses (MHS). These nine MHS contain at least six levels that identify each group's severity, though some CRG groups consider only five, four or two. The aggregation level that considers the nine MHS and the six severity levels is called an Aggregated Clinical Risk Group 3 (ACRG3) [7].

The second concern addresses how to model healthcare expenditures, as these dependent variables typically have distributions which show right-skewness with a large mass at zero [15]. 
Ordinary least squares (OLS) lineal regression based on normal distribution has traditionally been used [4,16-18]. To correct the right-skewness of healthcare expenditure, early approaches considered a transformation of the data, such as a logarithmic transformation through an OLS regression model. However, there is a risk of the error term of model. To solve this, it is possible to go from the $E(\ln (y / x)$ to the $\ln (\mathrm{E}(\mathrm{y} / \mathrm{x})$ by retransformation $[19,20]$. Other authors have begun to use generalized linear models (GLM) [21-27]. GLM methodology offers advantages over OLS regression: 1) the data dealt need not follow a normal distribution, nor meet homoscedasticity criteria; 2) it provides estimates of the $\ln (\mathrm{E}(\mathrm{y} / \mathrm{x})$ and $\mathrm{E}(\mathrm{y} / \mathrm{x})$ directly, without any requirement for retransformation [28]. GLM are characterised by the possibility of adopting different types of probability distributions (Gamma, Poisson, Binominal, etc.).

Another problem in analysing healthcare expenditure is a possible large mass of observations with zero-cost [29]. Different studies have adopted different solutions for this: 1) adding a positive constant $\mathrm{k}$ to the costs, thus modelling the $\log (\cos t+\mathrm{k})$, usually in an OLS framework [8]. This has the previously mentioned problem of back-transformation [19], which can be avoided by using GLM and not taking into account different behaviours of patients with zero-costs. 2) using the Tobit model based on the concept of latent variable. 3) using a mixed model that explicitly takes into account the different nature of the populations, one with positive and the other with zero-cost [30]. The expectation is split in two parts, the first modelling the probability of any expenditure, based on the full sample. The second models the actual level of expenditure conditionally to $c>0$. Here, the following distinctions are made [31]: 1) if the distribution allows for zeros, then those models with a separate zero cost mechanism are called zero-inflated models; 2 ) if the distribution does not allow for zeros, those models with a separate zero cost mechanism are commonly called two-part models. The two-part model is based on a statistical decomposition of the density of the outcome into a process that generates zeros and a process that generates positive values [15].

It must be kept in mind that the two-part models can also have the problem of retransformation if the second part of the model is based on a transformation, e.g. a logarithmic transformation. To avoid this, the substitution of the OLS model part for a Gamma model is a valid option [29].

In Spain, $C R G$ is used by various autonomous regions and organisations: the Basque country, the Valencian Community (VC) [32,33] and the Baix Empordà (Girona) [11,34-37]. In these cases, the regression models used are adjusted by OLS either in their original form or through the logarithmic transformation of the dependent variable. More recently, the integrated cost of patients with 
expenditure other than zero has been modelled using GLM [38], as has the pharmaceutical prescription expenditure using a variant of CRG called adjusted morbidity groups (AMG) [39].

Thus, the two main purposes of this article are: 1) to model the expenditure of integrated health care (hospital, primary health care (PHC) and pharmaceutical prescription) for the entire population of a health district of the VC according to multimorbidity, using CRG. 2) to show how the predictive model is applied to the allocation of health budgets.

Previous works carried out in the VC $[32,40]$ have modelled the pharmaceutical expenditure for the whole population. However, the present work models the total health expenditure and, moreover, the expenditure for the whole population ( 0 cost included), which represents a new contribution compared with a previous work carried out in Girona [34].

The availability of a system that relates multimorbidity and expenditure is a highly relevant innovation for some health systems. As well as establishing predictive budgets at different levels of the system for the health district, health centre and practitioner, it can be used to assign other resources, such as human resources.

\section{Materials and Methods}

\subsection{Design and study area}

This is a cross-sectional study of total healthcare expenditure and its application in clinical management using predictive models. A database of the 156,811 inhabitants was available that make up the Denia Health District (DHD) of the VC that is managed according public-private partnership agreement [12]. For each individual, the database contains age, sex, MHS, severity level, pharmaceutical expenditure (in euros), PHC expenditure (in euros) and hospital expenditure (in euros). All data was taken from 2013.

\subsection{Sources of information}

From the Regional Ministry of Health (Conselleria de Sanitat), the information sources on the patients are: the Population Information System (SIP), which holds the identifying and demographic variables of the patient; the Ambulatory Information System (SIA-GAIA), which gathers the pharmacy prescriptions expenditure and PHC activity; and the Patient Classification System, which classifies the 
patient into a CRG (standard version 1.6). This information is available for all the health districts, including DHD.

Information on hospital expenditure for the DHD was provided by the Denia Hospital Management Control services, and includes costs for hospitalisation, surgery, outpatient consultations, laboratory, medical imaging, outpatient oncology care, dialysis and referrals to other hospitals. PHC expenditure was not obtained directly from the accountancy services of the Regional Ministry of Health, but was calculated from the official prices according to the Public Tariffs Law (Ley de Tasas) of the VC [41] and the number of contacts made with the health service.

\subsection{Modelling}

We used two-part models to estimate four dependent variables: total healthcare expenditure, pharmaceutical prescription expenditure, PHC expenditure and hospital expenditure. Only the predictions for total healthcare expenditure were used to construct a capitation model and assign budgets to VC health districts.

With two-part models there are four main modelling choices [15]. The first is to select the first part of two-part model. The first part is usually modelled via a probit:

$$
P_{r}\left(c_{i}>0 / x_{i}\right)=\phi(x, \beta)
$$

Where $\phi$ represents the standard normal cumulative distribution function, or via a logit:

$$
P_{r}\left(c_{i}>0 / x_{i}\right)=\frac{e^{x^{\prime} \beta}}{1+e^{x^{\prime} \beta}}
$$

We chose a logit model to define the probability of costs greater than 0 . The second and third choices correspond to the modelling of positive costs, using the Manning and Mullahy algorithm [28,38,42].

Distributions considered for the positive costs are an appropriate model in the log-linear OLS or the GLM class with a log link:

$$
\begin{aligned}
& \text { Log-linear OLS: } \log \mathrm{c}_{i}=\alpha+\beta X_{i}+\varepsilon_{i} \\
& \text { GLM with a } \log \operatorname{link}: \mathrm{c}_{i}=\mathrm{e}^{\alpha+\beta X_{i}+\varepsilon_{i}}
\end{aligned}
$$

The final result of the two-part model is obtained by [29]:

$$
E\left(c_{i} / x_{i}\right)=P_{r}\left(c_{i}>0 / x_{i}\right) E\left(c_{i} / x_{i}, c_{i}>0\right)
$$

The fourth choice concerns the specification of the linear index. 
We further designed five models with different explanatory variables. Model 1: age and sex; Model 2: MHS and severity; Model 3: MHS, severity, age and sex; Model 4: ACRG3; Model 5: ACRG3, age and sex. The variables sex, ACRG3, MHS and severity were dummy variables. The variable sex took the value 1 if it was male and 0 otherwise.

We estimated the two-part model and statistical test in Stata, using the twopm command $[43,44]$.

\subsection{Specification tests, goodness of fit and validating the model}

We tested the specification of the explanatory variables in the second part by conducting Pregibon's link test [45], a modified Hosmer-Lemeshow test [46], the Root Mean Square Error (RMSE), the Mean Absolute Percentage Error (MAPE), the Median Absolute Percentage Error (MEDAPE) and the adjusted coefficient of determination $\left(R^{2}\right)$ between the logarithm of the current values and those predicted by the models.

Using the model for total healthcare expenditure, an estimated total expenditure for each value of the explanatory variables was obtained. To corroborate that the selected model was also the one with the strongest predictive power for the total actual expenditure, the mean predictive of total actual cost by decile will be calculated. Also we will plot the predicted means across the range of predicted values for the predictive total expenditure per decile. This enables visual detection of the MHS that have greater variability than the mean [42].

\subsection{Obtaining weights and case-mix system}

The weights of each multimorbility group were obtained from the quotient between the healthcare expenditure of each multimorbility group and the healthcare expenditure of the healthy group. These weights were used to obtain the adjusted patients for each district in the VC (number of individuals of each ACRG3 * weight of ACRG3) and their case-mix (adjusted patients/total population) for adjusted capitation budgeting purposes.

This research was approved by the Behavioural Research Ethics Board at the Generalitat Valenciana on January 30, 2014, with protocol code RUTFAR- 2013-01, version of 19 December 2013. The Research Commission of Denia Health District approved the project on 12 February 2015. 


\section{Results}

\subsection{Descriptive analysis}

Table 1 shows the number of individuals, average age, female population and total healthcare expenditure ( $€$ /inhabitant) for each MHS and severity level. The patients with the highest average expenditure were those in MHS 9, with an average of $€ 14,423$.

Generally, the total average healthcare expenditure increases with the number and intensity of chronic diseases. The high standard deviation and a median value that was notably lower than the average in each MHS indicates wide variability in expenditure and a high concentration in a small part of the population. The average age also increases systematically with the number of chronic diseases, going from 33.8 years old for the healthy status to reach 75.9 in MHS 7. However, in MHS 8 and 9, which refer to malignant diseases and catastrophic conditions with a strong economic impact (cystic fibrosis, transplants, etc.), the average age descends, as these conditions are less tied to an age group than the other chronic conditions in MHS 6 and 7. MHS 9 with severity level 6 is the MHS with the highest average expenditure $(€ 42,881)$. ACRG3 10, the healthy group, represents $54.7 \%$ of the total population.

\subsection{Econometric modelling of healthcare expenditure according to morbidity}

The first modelling of the probability of any expenditure does not require a decision on the model to be chosen. Table 4, therefore, includes only results from the model selected. Table 2 shows the test results by model selection for second part between the five models designed with different explanatory variables. In all cases the kurtosis of residual analysis (log scale) of the GLM log-link estimator were higher than 3. This means that, according to the algorithm used, we must conduct log-OLS estimation instead of GLM. According to results of the modified Hosmer-Lemeshow, Pregibon's link and MEDAPE, model 4 achieved the highest level of specification. This model, which included the 38 multimorbidity groups of ACRG3 aggregation level as independent variable, had an adjusted $R^{2}$ of $46.4 \%$, which was not the highest, but sufficient. Therefore, we used this model for analysing the other cost dependent variables and designing the predictive case-mix system for the health district's budget assignation.

The test results of the model's estimation for pharmaceutical prescription, PHC and hospital expenditures are shown in Table 3. The pharmaceutical predictive model achieved the best results with $55.62 \%$ of adjusted $R^{2}$. All models had a good specification. 
In Table 4 (columns 2 and 3) we show the results from the two-part models for total healthcare expenditure, using multimorbidity groups classified by ACRG3. To obtain the predicted expenditure value for each group we retransformed the coefficients and also considered Duan's smearing estimator $(1,757)$ (column 4). Column 5 of Table 4 shows the total healthcare expenditure estimated from multiplying non-zero probability obtained from column 2 by the value of column 4 .

Figure 1 illustrates the predicted means across the range of predicted values for the predictive total expenditure per decile. The actual decil means form a $45^{\circ}$ line. However, all groups of MSH 9 and group of MSH 7 which indicates they are under-predicted, while others (ACRG3 74, ACRG3 76 and ACRG3 84) fall below the line, which indicates they are over-predicted.

\subsection{Development of a case-mix model}

The process for the calculation of the weights to establish the case-mix system by multimorbidity groups is given in the in the last column of Table 4. From the value of column 5, the relative weight is calculated in column 6 .

Once the relative weights for each ACRG3 have been calculated, they are multiplied by the number of existing patients in each group of each $\mathrm{VC}$ health district to obtain the number of patients adjusted by morbidity. Dividing the value obtained in each health district by the number of total patients for that health district provides the case-mix. The results of these calculations are shown in figure 2 . The districts with higher morbidity will require higher capitation financing. The case-mix oscillates between 3.8 and 4.8 .

\section{Discussion}

The direct predecessor of this study was a modelling of pharmaceutical prescription expenditure from CRG stratification, which was also carried out in the VC $[32,47]$. However, the main contribution of the present work is to analyse not only prescription pharmaceutical expenditure, but also expenditure in PHC and hospital settings, both together and separately, for the entire population of 156,811 in the health districts of the VC, which signifies a notable advance in healthcare expenditure modelling. 
In this work we use a two-part model [15] as opposed to the $\log (\operatorname{cost}+\mathrm{k})$ in an OLS with which previous works were carried out $[32,47]$, and in other works $[16,48,49]$. In the second part of the model, log-linear OLS were always chosen, both for the different models of total expenditure and the different categories of expenditure, as opposed to other works where GLM has sometimes been chosen $[38,42]$.

The adjusted $\mathrm{R}^{2}$ of $46.4-49.4 \%$ were similar to that obtained in other previous studies that used different patient classification systems. For example, a study carried out in Canada [16] used OLS regression and measured the explanatory and predictive quality of ACGs for total healthcare expenditure, which was 40\%. Likewise, another study in Taiwan [48], relating total healthcare expenditure and ACGs through OLS regression, obtained an $\mathrm{R}^{2}$ of $41.1 \%$.

An $\mathrm{R}^{2}$ of $48.3 \%$ in pharmaceutical expenditure has been obtained by OLS regression, using a sample of 81,873 individuals in Spain [49], which is a similar figure to that of the present work. Nevertheless, it is important to note that the above - mentioned study only encompassed those patients in contact with the healthcare system, either out - or inpatients, which means that their research did not reflect those subjects who did not use the healthcare system. Conversely, our work covered the whole population in the $\mathrm{DHD}$, including those inhabitants with a zero cost, providing another important contribution.

Hospital expenditure had the lowest adjusted $\mathrm{R}^{2}(33.01 \%)$ of the three main expenditure categories, due to treatment of acute conditions requiring surgery, hospitalisation and cancer treatment, among others. This wide variability in the same MHS is because not all chronic patients classified in one group require hospitalisation. Thus, for example, a patient from MHS 6 may present a series of complications, while another from the same MHS might not. This means hospital expenditure is more heterogeneous in any given MHS with the same severity level, as even the same disease may require a different number of hospitalisation days, several types and numbers of surgical interventions, etc. Those patients also classified within the MHS may register hospital expenditure for a musculoskeletal system or some other condition. We must also take into account that pregnant women, classified in the healthy status, also use hospital resources during their pregnancy and delivery. On the other hand, pharmaceutical prescription expenditure had the best adjusted $\mathrm{R}^{2}(55.62 \%)$.

The analysis of expenditure by deciles shows a greater deviation for patients from MHS 9 and high severity levels. This may be due to these groups having a very low population and a high standard deviation. It may be the case that these groups are not fully represented in the models and new adjustments may be needed with elderly populations to ratify the obtained models. 
There are great differences in the case-mix between the health districts, ranging from 3.8 to 4.8 . Therefore, in terms of establishing a case-mix system for budget allocation, the model explained in this study might be a useful approach in future applications, as previously shown for pharmaceutical prescription expenditure adjusted by morbidity with CRG [8].

While the model presented by Monterde et al [39] explained the pharmaceutical expenditure of the AMG using statistical GLM models adjusted to Poisson distribution, we concur with Inoriza et al. [36] on the methodological limitations of this proposal and the need to establish technical comparisons with models using CRG.

\section{Limitations}

The main limitation of this study was the population size considered, as it would have been desirable to have information on the total expenditure for the patients in various Health Districts. This, however, was not possible. Moreover, the PHC expenditure used in this study was obtained by applying an official standard tariff to the number of contacts made with this healthcare service, a figure obtained from estimations as this accounting information was also lacking. The case-mix model for the VC was established by extrapolating the weights obtained in the model for the DHD to the entire VC population. It would be recommendable for future research to be able to count on the whole population of the field of study.

Regarding the modelling, we chose model 4 according to results of the modified Hosmer-Lemeshow, Pregibon's link and MEDAPE. However, model 4 had the greatest RMSE. This RMSE would possibly be reduced by increasing the size of the sample by adding more health districts.

Another limitation, also regarding the information available, concerns home and long term residential care. This information was unavailable and therefore could not be included. This needs to be included in future studies to obtain the total healthcare expenditure. Other studies with a similar setting to ours [38] also lack this information.

Regarding external validity and extrapolation of the results, two requirements must be met. Firstly, that the multimorbidity classification system used is CRG, and secondly, that the cost structure is similar. However, the methodology and system offered in this work can be replicated with another kind of variables. 
In any case, considerable variability exists in the typology of research and tools used for clinical risk adjustment. Thus, it would be worthwhile for more healthcare administration institutions to conduct studies in this field in order to be able to compare results and obtain feedback [36].

\section{Conclusions}

Multimorbidity grouping obtained from CRG patient classification system is a valid measure to predict healthcare expenditure. Good predictive power was achieved for pharmaceutical expenditure and total healthcare expenditure. Two-part models provided better estimations than other econometric models used for modelling healthcare expenditures.

\section{References}

[1] Tinetti ME, Fried TR, Boyd CM. Designing health care for the most common chronic condition-multimorbidity. JAMA 2012;307:2493-4. doi:10.1001/jama.2012.5265.

[2] Palmer K, Marengoni A, Forjaz MJ, Jureviciene E, Laatikainen T, Mammarella F, et al. Multimorbidity care model: Recommendations from the consensus meeting of the Joint Action on Chronic Diseases and Promoting Healthy Ageing across the Life Cycle (JA-CHRODIS). Health Policy (New York) 2018;122:4-11. doi:10.1016/j.healthpol.2017.09.006.

[3] Tsiachristas A, van Ginneken E, Rijken M. Tackling the challenge of multi-morbidity: Actions for health policy and research. Health Policy (New York) 2018;122:1-3. doi:10.1016/j.healthpol.2017.11.011.

[4] Starfield B, Weiner J, Mumford L, Steinwachs D. Ambulatory care groups: a categorization of diagnoses for research and management. Health Serv Res 1991;26:53-74.

[5] Ash A, Porell F, Gruenberg L, Sawitz E, Beiser A. Adjusting Medicare capitation payments using prior hospitalization data. Health Care Financ Rev 1989;10:17-29.

[6] Pope GC, Kautter J, Ellis RP, Ash AS, Ayanian JZ, Lezzoni LI, et al. Risk adjustment of Medicare capitation payments using the CMS-HCC model. Health Care Financ Rev 2004;25:119-41.

[7] Hughes J, Verill R, Eisenhandler J, Goldfield N, Muldoon J, Neff J. Clinical Risk Groups (CRGs): A Classification System for Risk-Adjusted Capitation-Based Payment and Health Care Management. Med Care 2004;42:81-90.

[8] Vivas-Consuelo D, Usó-Talamantes R, Guadalajara-Olmeda N, Trillo-Mata J-L, Sancho-Mestre C, Buigues-Pastor $\mathrm{L}$. Pharmaceutical cost management in an ambulatory setting using a risk adjustment tool. BMC Health Serv Res 2014;14:462. doi:10.1186/1472-6963-14-462.

[9] Finison K, Mohlman M, Jones C, Pinette M, Jorgenson D, Kinner A, et al. Risk-adjustment methods for all-payer comparative performance reporting in Vermont. BMC Health Serv Res 2017;17:58. doi:10.1186/s12913-017-2010-0.

[10] Hoefgen ER, Andrews AL, Richardson T, Hall M, Neff JM, Macy ML, et al. Health Care Expenditures and Utilization for Children With Noncomplex Chronic Disease. Pediatrics 2017;140. 
[11] Coderch J, Sánchez-Pérez I, Ibern P, Carreras M, Pérez-Berruezo X, Inoriza JM. Predicción del riesgo individual de alto coste sanitario para la identificación de pacientes crónicos complejos. Gac Sanit 2014;28:292-300. doi:https://doi.org/10.1016/j.gaceta.2014.03.003.

[12] Caballer Tarazona V, Guadalajara Olmeda N, Vivas Consuelo D, Clemente Collado A. [Impact of Morbidity on Health Care Costs of a Department of Health through Clinical Risk Groups. Valencian Community, Spain]. Rev Esp Salud Publica 2016;90:e1-15.

[13] Berry JG, Hall M, Cohen E, O'Neill M, Feudtner C. Ways to Identify Children with Medical Complexity and the Importance of Why. J Pediatr 2015;167:229-37. doi:10.1016/j.jpeds.2015.04.068.

[14] Brotons C, Moral I, Pitarch M, Sellarès J. Estudio evaluativo de los costes asistenciales en atención primaria. Atención Primaria 2007;39:485-9.

[15] Deb P, Norton EC. Modeling Health Care Expenditures and Use. Annu Rev Public Heal 2018;39:489_505. doi:10.1146/annurev-publhealth-040617-013517.

[16] Reid RJ, MacWilliam L, Verhulst L, Roos N, Atkinson M. Performance of the ACG case-mix system in two Canadian provinces. Med Care 2001;39:86-99. doi:10.1097/00005650-200101000-00010.

[17] Engstrom SG, Carlsson L, Ostgren C-J, Nilsson GH, Borgquist LA. The importance of comorbidity in analysing patient costs in Swedish primary care. BMC Public Health 2006;6:36. doi:10.1186/1471-24586-36.

[18] Kuo RN, Lai M. The influence of socio-economic status and multimorbidity patterns on healthcare costs: a six-year follow-up under a universal healthcare system. Int J Equity Health 2013;12:69. doi:10.1186/1475-9276-12-69.

[19] Duan N. Smearing estimate - a nonparametric retransformation method. J Am Stat Assoc 1983;78:60510.

[20] Manning WG. The logged dependent variable, heteroscedasticity, and the retransformation problem. J Health Econ 1998. doi:10.1016/S0167-6296(98)00025-3.

[21] Dierh P, Donald LP, Bild DE, Burke GL, Williamson JD. Predicting future years of healthy life for olther adults. J Clin Epidemiol 1998;51. doi:10.1016/S0895-4356(97)00298-9.

[22] Griswold BM, Lipscomb J. Analyzing Health Care Costs : A Comparison of Statistical Methods Motivated by Medicare Colorectal Cancer Charges. Biostatistics 2004;1:1-23.

[23] Manning WG, Basu A, Mullahy J. Generalized modeling approaches to risk adjustment of skewed outcomes data. J Health Econ 2005;24:465-88. doi:http://dx.doi.org/10.1016/j.jhealeco.2004.09.011.

[24] Moran JL, Solomon PJ, Peisach AR, Martin J. New models for old questions: generalized linear models for cost prediction. J Eval Clin Pract 2007;13:381-9. doi:10.1111/j.1365-2753.2006.00711.x.

[25] Basu A, Manning WG. Issues for the Next Generation of Health Care Cost. Med Care 2009;47:109-14.

[26] Mihaylova B, Briggs A, O'Hagan A, Thompson SG. Review of Statistical Methods for Analysing Healthcare Resources and Costs. Health Econ 2011;20:897-916. doi:10.1002/hec.1653.

[27] Hanley GE, Morgan S, Reid RJ. Explaining prescription drug use and expenditures using the adjusted clinical groups case-mix system in the population of British Columbia, Canada. Med Care 2010;48:4028. doi:10.1097/MLR.0b013e3181ca3d5d.

[28] Manning WG, Mullahy J. Estimating log models : to transform or not to transform ? ₹. J Health Econ 
2001;20:461-94.

[29] Gregori D, Petrinco M, Bo S, Desideri A, Merletti F, Pagano E. Regression models for analyzing costs and their determinants in health care: an introductory review. Int J Qual Heal Care 2011;23:331-41.

[30] Buntin MB, Zaslavsky AM. Too much ado about two-part models and transformation? Comparing methods of modeling Medicare expenditures. J Health Econ 2004. doi:10.1016/j.jhealeco.2003.10.005.

[31] Daggy JK, Thomas J, Craig BA. Modeling correlated healthcare costs. Expert Rev Pharmacoeconomics Outcomes Res 2011. doi:10.1586/erp.10.92.

[32] Vivas-Consuelo D, Usó-Talamantes R, Trillo-Mata JL, Caballer-Tarazona M, Barrachina-Martínez I, Buigues-Pastor L. Predictability of pharmaceutical spending in primary health services using Clinical Risk Groups. Health Policy (New York) 2014;116:188-95. doi:10.1016/j.healthpol.2014.01.012.

[33] Caballer-Tarazona V, Guadalajara-Olmeda N, Vivas-Consuelo D, Clemente-Collado A. Impact of Morbidity on Health Care Costs of a Department of Health through Clinical Risk Groups. Valencian Community, Spain. Rev Esp Salud Publica 2016;90.

[34] Inoriza JM, Pérez M, Cols M, Sánchez I, Carreras M, Coderch J. Análisis de la población diabética de una comarca: perfil de morbilidad, utilización de recursos, complicaciones y control metabólico. Atención Primaria 2013;45:461-75. doi:https://doi.org/10.1016/j.aprim.2013.04.007.

[35] Carreras M, Ibern P, Coderch J, Sánchez I, Inoriza JM. Estimating lifetime healthcare costs with morbidity data. BMC Health Serv Res 2013;13:1-11. doi:10.1186/1472-6963-13-440.

[36] Inoriza JM, Pérez $X$, Carreras $M$, Cordech J. MORBIDITY AND HEALTHCARE COSTS: TOWARDS A BENCHMARKING? Rev Esp Salud Pública 2016;90:22-4.

[37] Inoriza JM, Coderch J, Carreras M, Vall-Ilosera L, García-Goñi M, Lisbona JM, et al. La medida de la morbilidad atendida en una organización sanitaria integrada. Gac Sanit 2009;23:29-37. doi:10.1016/j.gaceta.2008.02.003.

[38] Carreras M, Sánchez-Pérez I, Ibern P, Coderch J, Inoriza JM. Analysing the Costs of Integrated Care: A Case on Model Selection for Chronic Care Purposes. Int J Integr Care 2016;16:10. doi:10.5334/ijic.2422.

[39] Monterde D, Vela E, Clèries M. Los grupos de morbilidad ajustados: nuevo agrupador de morbilidad poblacional de utilidad en el ámbito de la atención primaria. Aten Primaria 2016;48:674-82. doi:10.1016/j.aprim.2016.06.003.

[40] Vivas D, Guadalajara N, Barrachina I, Trillo J-L, Usó R, de-la-Poza E. Explaining primary healthcare pharmacy expenditure using classification of medications for chronic conditions. Health Policy 2011;103:9-15. doi:10.1016/j.healthpol.2011.08.014.

[41] Conselleria de Economía Hacienda y Empleo. Decreto Legislativo 1/2005, de 25 de febrero, del Consell de la Generalitat, por el que se aprueba el Texto Refundido de la Ley de Tasas de la Generalitat. Revisión 20132013.

[42] Buntin MB, Zaslavsky AM. Too much ado about two-part models and transformation?: Comparing methods of modeling Medicare expenditures. J Health Econ 2004;23:525-42. doi:http://dx.doi.org/10.1016/j.jhealeco.2003.10.005.

[43] Belotti F, Deb P, Manning WG, Norton EC. twopm: Two-part models. Stata J 2015. doi:The Stata Journal.

[44] Deb P, Norton EC, Manning WG. Health Econometrics Using Stata. 2017. 
[45] Pregibon D. Goodness of Link Tests for Generalized Linear Models. Appl Stat 1980. doi:10.2307/2346405.

[46] Yu W, Xu W, Zhu L. A modified Hosmer-Lemeshow test for large data sets. Commun Stat - Theory Methods 2017. doi:10.1080/03610926.2017.1285922.

[47] Sancho-Mestre C, Vivas-Consuelo D, Alvis-Estrada L, Romero M, Usó-Talamantes R, Caballer-Tarazona $\mathrm{V}$. Pharmaceutical cost and multimorbidity with type 2 diabetes mellitus using electronic health record data. BMC Health Serv Res 2016;16:394. doi:10.1186/s12913-016-1649-2.

[48] Kuo RN, Lai M-S. Comparison of Rx-defined morbidity groups and diagnosis- based risk adjusters for predicting healthcare costs in Taiwan. BMC Health Serv Res 2010;10:126. doi:10.1186/1472-6963-10126.

[49] Sicras-Mainar A, Navarro-Artieda R. [Validating the Adjusted Clinical Groups [ACG] case-mix system in a Spanish population setting: a multicenter study]. Gac Sanit 2009;23:228-31. doi:10.1016/j.gaceta.2008.04.005.

\section{List of abbreviations}

ACG: Adjusted Clinical Groups

ACRG3: Aggregated Clinical Risk Group 3

CRG: Clinical Risk Groups

DHD: Denia Health District

GLM: Generalised linear models

MHS: Mean health statuses

MAPE: the Mean Absolute Percentage Error

MEDAPE: the Median Absolute Percentage Error

RMSE: Root Mean Square Error

OLS: ordinary least squares

$\mathrm{R}^{2}$ : Coefficient of determination

PHC: Primary health care

VC: Valencian Community 
Table 1. Average total healthcare expenditure and population distribution by mean health status and severity level

\begin{tabular}{|c|c|c|c|c|c|c|c|c|c|}
\hline \multirow{2}{*}{$\begin{array}{l}\text { Mean Health } \\
\text { Status }\end{array}$} & & \multicolumn{7}{|c|}{ Severity level } & \multirow[b]{2}{*}{ TOTAL } \\
\hline & & 0 & 1 & 2 & 3 & 4 & 5 & 6 & \\
\hline \multirow{4}{*}{1 Healthy } & Population (\%) & $\begin{array}{r}85,668 \\
(54.7 \%) \\
\end{array}$ & & & & & & & $\begin{array}{r}85,668 \\
(54.7 \%) \\
\end{array}$ \\
\hline & Mean age & 33.8 & & & & & & & 33.8 \\
\hline & Female Population (\%) & $47.9 \%$ & & & & & & & $47.9 \%$ \\
\hline & $\begin{array}{l}\text { Health Cost (€/inhab) } \\
\text { Mean (SD) }\end{array}$ & $\begin{array}{l}240.0 \\
(750) \\
\end{array}$ & & & & & & & $\begin{array}{r}240.01 \\
(750) \\
\end{array}$ \\
\hline \multirow{4}{*}{$\begin{array}{l}2 \text { History of } \\
\text { Significant Acute } \\
\text { Disease }\end{array}$} & Population (\%) & $\begin{array}{r}6,142 \\
(3.9 \%) \\
\end{array}$ & & & & & & & $\begin{array}{r}6,142 \\
(3.9 \%) \\
\end{array}$ \\
\hline & Mean age & 36.9 & & & & & & & 36.9 \\
\hline & Female Population (\%) & $57.7 \%$ & & & & & & & $57.7 \%$ \\
\hline & $\begin{array}{l}\text { Health Cost (€/inhab) } \\
\text { Mean (SD) }\end{array}$ & $\begin{array}{l}1,013.1 \\
(2,936)\end{array}$ & & & & & & & $\begin{array}{l}1013.1 \\
(2,936) \\
\end{array}$ \\
\hline \multirow{4}{*}{$\begin{array}{l}3 \text { Single Minor } \\
\text { Chronic Disease } \\
\text { Level }\end{array}$} & Population (\%) & & $\begin{array}{l}14,805 \\
(9.4 \%) \\
\end{array}$ & $\begin{array}{r}805 \\
(0.5 \%) \\
\end{array}$ & & & & & $\begin{array}{r}15,610 \\
(9.9 \%) \\
\end{array}$ \\
\hline & Mean age & & 47.5 & 42.9 & & & & & 47.3 \\
\hline & Female Population (\%) & & $56.2 \%$ & $65.7 \%$ & & & & & $56.7 \%$ \\
\hline & $\begin{array}{l}\text { Health Cost (€/inhab) } \\
\text { Mean (SD) }\end{array}$ & & $\begin{array}{r}632.9 \\
(1,781) \\
\end{array}$ & $\begin{array}{l}1,549.0 \\
(4,636) \\
\end{array}$ & & & & & $\begin{array}{r}680.1 \\
(2,039) \\
\end{array}$ \\
\hline \multirow{4}{*}{$\begin{array}{l}4 \text { Minor Chronic } \\
\text { Disease in } \\
\text { Multiple Organ } \\
\text { Systems }\end{array}$} & Population (\%) & & $\begin{array}{r}4,088 \\
(2.6 \%) \\
\end{array}$ & $\begin{array}{r}1,425 \\
(0.9 \%) \\
\end{array}$ & $988(0.6 \%)$ & $106(0.1 \%)$ & & & $\begin{array}{r}6,607 \\
(4.2 \%) \\
\end{array}$ \\
\hline & Mean age & & 56.6 & 62.1 & 58.6 & 59.7 & & & 58.1 \\
\hline & Female Population (\%) & & $63.7 \%$ & $70.2 \%$ & $76.9 \%$ & $78.3 \%$ & & & $67.4 \%$ \\
\hline & $\begin{array}{l}\text { Health Cost (€/inhab) } \\
\text { Mean (SD) }\end{array}$ & & $\begin{array}{r}931.8 \\
(1,400) \\
\end{array}$ & $\begin{array}{l}1,288.1 \\
(1,672)\end{array}$ & $\begin{array}{l}1,629.9 \\
(2,061)\end{array}$ & $\begin{array}{l}2,168.2 \\
(1,618)\end{array}$ & & & $\begin{array}{l}1,133.9 \\
(1,605)\end{array}$ \\
\hline \multirow{4}{*}{$\begin{array}{l}5 \text { Single } \\
\text { Dominant or } \\
\text { Moderate } \\
\text { Chronic Disease }\end{array}$} & Population (\%) & & $\begin{array}{r}18,364 \\
(11.7 \%) \\
\end{array}$ & $\begin{array}{r}4,495 \\
(2.9 \%) \\
\end{array}$ & $\begin{array}{r}1,483 \\
(0.9 \%) \\
\end{array}$ & $183(0.1 \%)$ & $313(0.2 \%)$ & $\begin{array}{r}12 \\
(0.0 \%) \\
\end{array}$ & $\begin{array}{r}24,856 \\
(15.8 \%) \\
\end{array}$ \\
\hline & Mean age & & 54.6 & 57.3 & 61.1 & 72.6 & 68.5 & 60.2 & 55.8 \\
\hline & Female Population (\%) & & $52.1 \%$ & $52.9 \%$ & $42.3 \%$ & $41.5 \%$ & $49.2 \%$ & $33.3 \%$ & $51.5 \%$ \\
\hline & $\begin{array}{l}\text { Health Cost (€/inhab) } \\
\text { Mean (SD) }\end{array}$ & & $\begin{array}{l}1,360.4 \\
(2,615) \\
\end{array}$ & $\begin{array}{l}1,990.8 \\
(2,908) \\
\end{array}$ & $\begin{array}{l}2,663.0 \\
(4,040) \\
\end{array}$ & $\begin{array}{r}4,806.2 \\
(21,399) \\
\end{array}$ & $\begin{array}{l}3,301.9 \\
(4,477) \\
\end{array}$ & $\begin{array}{l}5,962.2 \\
(8,517) \\
\end{array}$ & $\begin{array}{l}1,604.2 \\
(3,384) \\
\end{array}$ \\
\hline \multirow{4}{*}{$\begin{array}{l}6 \text { Significant } \\
\text { Chronic Disease } \\
\text { in Multiple } \\
\text { Organ Systems }\end{array}$} & Population (\%) & & $\begin{array}{r}8,244 \\
(5.3 \%) \\
\end{array}$ & $\begin{array}{r}3,606 \\
(2.3 \%) \\
\end{array}$ & $\begin{array}{r}2,137 \\
(1.4 \%) \\
\end{array}$ & $\begin{array}{r}1,202 \\
(0.8 \%) \\
\end{array}$ & $480(0.3 \%)$ & $\begin{array}{r}37 \\
(0.0 \%) \\
\end{array}$ & $\begin{array}{r}15,706 \\
(10.0 \%) \\
\end{array}$ \\
\hline & Mean age & & 67.6 & 70.2 & 71.8 & 74.0 & 75.8 & 73.1 & 69.5 \\
\hline & Female Population (\%) & & $57.4 \%$ & $50.3 \%$ & $50.2 \%$ & $50.4 \%$ & $47.9 \%$ & $54.1 \%$ & $54.0 \%$ \\
\hline & $\begin{array}{l}\text { Health Cost (€/inhab) } \\
\text { Mean (SD) }\end{array}$ & & $\begin{array}{l}2,337.1 \\
(3,168)\end{array}$ & $\begin{array}{l}3,468.6 \\
(5,003)\end{array}$ & $\begin{array}{l}4,182.3 \\
(5,550)\end{array}$ & $\begin{array}{l}4,924.8 \\
(5,210)\end{array}$ & $\begin{array}{l}5,964.1 \\
(6,080)\end{array}$ & $\begin{array}{r}10,244.7 \\
(9,801)\end{array}$ & $\begin{array}{l}3,176.5 \\
(4,443)\end{array}$ \\
\hline \multirow{4}{*}{$\begin{array}{l}7 \text { Dominant } \\
\text { Chronic Disease } \\
\text { In Three or More } \\
\text { Organ Systems }\end{array}$} & Population (\%) & & $\begin{array}{r}292 \\
(0.2 \%) \\
\end{array}$ & $\begin{array}{r}219 \\
(0.1 \%) \\
\end{array}$ & $\begin{array}{r}423 \\
(0.3 \%) \\
\end{array}$ & $\begin{array}{r}96 \\
(0.1 \%) \\
\end{array}$ & $\begin{array}{r}39 \\
(0.0 \%) \\
\end{array}$ & $\begin{array}{r}10 \\
(0.0 \%) \\
\end{array}$ & $\begin{array}{r}1,079 \\
(0.7 \%) \\
\end{array}$ \\
\hline & Mean age & & 74.4 & 75.5 & 76.6 & 78.8 & 76.2 & 68.6 & 75.9 \\
\hline & Female Population (\%) & & $45.2 \%$ & $40.6 \%$ & $42.8 \%$ & $46.9 \%$ & $20.5 \%$ & $30.0 \%$ & $42.4 \%$ \\
\hline & $\begin{array}{l}\text { Health Cost (€/inhab) } \\
\text { Mean (SD) }\end{array}$ & & $\begin{array}{l}3,894.4 \\
(4,388) \\
\end{array}$ & $\begin{array}{l}4,863.0 \\
(4,078) \\
\end{array}$ & $\begin{array}{l}6,242.8 \\
(6,782) \\
\end{array}$ & $\begin{array}{l}8,122.9 \\
(9,333) \\
\end{array}$ & $\begin{array}{l}9,780.4 \\
(6,891) \\
\end{array}$ & $\begin{array}{l}11,230.0 \\
(11,967)\end{array}$ & $\begin{array}{r}5,667.6 \\
(6,297) \\
\end{array}$ \\
\hline \multirow{4}{*}{$\begin{array}{l}8 \text { Dominant, } \\
\text { Metastatic, and } \\
\text { Complicated } \\
\text { Malignancies }\end{array}$} & Population (\%) & & $\begin{array}{r}107 \\
(0.1 \%) \\
\end{array}$ & $\begin{array}{r}249 \\
(0.2 \%) \\
\end{array}$ & $\begin{array}{r}226 \\
(0.2 \%) \\
\end{array}$ & $\begin{array}{r}81 \\
(0.1 \%) \\
\end{array}$ & $\begin{array}{r}23 \\
(0.0 \%) \\
\end{array}$ & & $\begin{array}{r}686 \\
(0.4 \%) \\
\end{array}$ \\
\hline & Mean age & & 58.1 & 63.7 & 65.6 & 66.9 & 63.3 & & 63.8 \\
\hline & Female Population (\%) & & $49.5 \%$ & $52.6 \%$ & $31.9 \%$ & $42.0 \%$ & $69.6 \%$ & & $44.6 \%$ \\
\hline & $\begin{array}{l}\text { Health Cost (€/inhab) } \\
\text { Mean (SD) }\end{array}$ & & $\begin{array}{r}7,138.8 \\
(13,497) \\
\end{array}$ & $\begin{array}{r}9,657.3 \\
(12,252) \\
\end{array}$ & $\begin{array}{l}10,445.9 \\
(12,752) \\
\end{array}$ & $\begin{array}{l}11,475.0 \\
(12,752) \\
\end{array}$ & $\begin{array}{r}10,194.7 \\
(6,241) \\
\end{array}$ & & $\begin{array}{r}9,757.9 \\
(16,917) \\
\end{array}$ \\
\hline \multirow{4}{*}{$\begin{array}{l}9 \text { Catastrophic } \\
\text { Conditions }\end{array}$} & Population (\%) & & $\begin{array}{r}59 \\
(0.0 \%) \\
\end{array}$ & $\begin{array}{r}221 \\
(0.1 \%) \\
\end{array}$ & $\begin{array}{r}87 \\
(0.1 \%) \\
\end{array}$ & $\begin{array}{r}59 \\
(0.1 \%) \\
\end{array}$ & $\begin{array}{r}28 \\
(0.0 \%) \\
\end{array}$ & $\begin{array}{r}11 \\
(0.0 \%) \\
\end{array}$ & $\begin{array}{r}463 \\
(0.30 \%) \\
\end{array}$ \\
\hline & Mean age & & 44.6 & 48.3 & 60.2 & 57.5 & 61.0 & 64.0 & 49.6 \\
\hline & Female Population (\%) & & $44.1 \%$ & $29.9 \%$ & $43.7 \%$ & $30.5 \%$ & $28.6 \%$ & $44.4 \%$ & $34.6 \%$ \\
\hline & $\begin{array}{l}\text { Health Cost (€/inhab) } \\
\text { Mean (SD) }\end{array}$ & & $\begin{array}{l}4,163.8 \\
(5,427) \\
\end{array}$ & $\begin{array}{l}7,835.8 \\
(4,088) \\
\end{array}$ & $\begin{array}{l}25,808.3 \\
(19,087)\end{array}$ & $\begin{array}{l}21,020.0 \\
(26,165)\end{array}$ & $\begin{array}{l}29,615.7 \\
(16,384)\end{array}$ & $\begin{array}{l}42,880.7 \\
(25,373)\end{array}$ & $\begin{array}{l}14,423.4 \\
(16,917)\end{array}$ \\
\hline TOTAL & $\begin{array}{l}\text { Population (\%) } \\
\text { Mean age }\end{array}$ & & & & & & & & $\begin{array}{r}156,811 \\
(100.0 \%) \\
43.8 \\
\end{array}$ \\
\hline
\end{tabular}




\begin{tabular}{|l|l|r|r|}
\hline & \begin{tabular}{r}
$51.1 \%$ \\
\hline \\
Hemale Population (\%) \\
Mean (SD)
\end{tabular} & 982.8 \\
\hline
\end{tabular}


Table 2. Manning-Mullahy algorithm results: Model choice for second part modelling of the positive total healthcare expenditure.

\begin{tabular}{|c|c|c|c|c|c|c|c|c|c|}
\hline $\begin{array}{l}\text { Explanatory } \\
\text { variables }\end{array}$ & $\mathrm{N}$ & Kurtosis & Model & $\begin{array}{r}\text { Hosmer- } \\
\text { Lemeshow } \\
(p-v a l u e)\end{array}$ & $\begin{array}{r}\text { Pregibon } \\
\text { link } \\
\text { (p-value) }\end{array}$ & $\begin{array}{r}\text { Adjusted } \\
\mathrm{R}^{2}\end{array}$ & RMSE & MAPE & MEDAPE \\
\hline $\begin{array}{l}\text { Model } 1 \\
\text { Age and sex }\end{array}$ & 127,072 & 6.68 & Log-OLS & $\begin{array}{r}58.53 \\
(0.000) \\
\end{array}$ & $\begin{array}{r}4383.64 \\
(0.000) \\
\end{array}$ & 0.133 & 1.37 & 0.19 & 0.15 \\
\hline $\begin{array}{l}\text { Model } 2 \\
\text { MHS and } \\
\text { severity }\end{array}$ & 127,072 & 4.67 & Log-OLS & $\begin{array}{r}25.28 \\
(0,000)\end{array}$ & $\begin{array}{l}384.28 \\
(0.000)\end{array}$ & 0.491 & 1.04 & 0.15 & 0.11 \\
\hline $\begin{array}{l}\text { Model } 3 \\
\text { MHS, } \\
\text { severity, age } \\
\text { and sex }\end{array}$ & 127,072 & 4.69 & Log-OLS & $\begin{array}{r}101.74 \\
(0.000)\end{array}$ & $\begin{array}{l}466.10 \\
(0.000)\end{array}$ & 0.494 & 1.05 & 0.15 & 0.11 \\
\hline $\begin{array}{l}\text { Model } 4 \\
\text { ACRG3 }\end{array}$ & 127,072 & 4.97 & Log-OLS & 0 (1.000) & 0 (1.000) & 0.464 & 10.75 & 0.17 & 0.11 \\
\hline $\begin{array}{l}\text { Model } 5 \\
\text { ACRG3, age } \\
\text { and sex }\end{array}$ & 127,072 & 4.59 & Log-OLS & $\begin{array}{r}87,03 \\
(0.000)\end{array}$ & $\begin{array}{r}27.61 \\
(0.000)\end{array}$ & 0.467 & 10.34 & 0.17 & 0.11 \\
\hline
\end{tabular}


Table 3. Manning-Mullahy algorithm results: Model choice for second part modelling for each positive expenditure type with ACRG3 independent variables.

\begin{tabular}{|l|r|r|r|r|r|r|r|r|r|}
\hline $\begin{array}{l}\text { Dependent } \\
\text { Variables }\end{array}$ & $\mathrm{N}$ & Kurtosis & Model & $\begin{array}{r}\text { Hosmer- } \\
\text { Lemeshow } \\
\text { (p-value) }\end{array}$ & $\begin{array}{r}\text { Pregibon } \\
\text { link } \\
\text { (p-value) }\end{array}$ & $\begin{array}{r}\text { Adjusted } \\
\mathrm{R}^{2}\end{array}$ & RMSE & MAPE & MEDAPE \\
\hline Pharmacy & 103,273 & 3.27 & Log-OLS & 0 (1.000) & $\begin{array}{r}0,000 \\
(1.000)\end{array}$ & 0.556 & 1.35 & 0.45 & 0.19 \\
\hline PHC & 124,703 & 4.20 & Log-OLS & $0(1.000)$ & $\begin{array}{r}0,000 \\
(1.000)\end{array}$ & 0.386 & 0.99 & 0.14 & 0.11 \\
\hline Hospital & 88,684 & 4.27 & Log-OLS & $0(1.000)$ & $\begin{array}{r}0,000 \\
(1.000)\end{array}$ & 0.330 & 2.1 & 0.25 & 0.20 \\
\hline
\end{tabular}


Table 4. Estimation of the relative weights of the ACRG3 from the results of the two-part model.

\begin{tabular}{|c|c|c|c|c|c|}
\hline$(1)$ & $\begin{array}{r}\text { First part } \\
\text { Logit } \\
\text { coefficients } \\
(2) \\
\end{array}$ & $\begin{array}{r}\text { Second part } \\
\text { Log OLS } \\
\text { coefficients } \\
\text { (3) }\end{array}$ & $\begin{array}{r}\text { Exp (Coefficients } \\
+ \text { Constant } \\
(2)) * \text { Smearing } \\
\text { Estimator }(1,757) \\
(4)(\text { Euro) }\end{array}$ & $\begin{array}{r}\text { Estimated value } \\
(5)=\mathrm{P}(\mathrm{c}>0) *(4) \text { (Euro) }\end{array}$ & $\begin{array}{l}\text { Relative weight } \\
(6)=(5) / 185.6 \\
\end{array}$ \\
\hline Constant & 0.78 & 7.778 & & & \\
\hline ACRG3 1 & 0.00 & -2.741 & 270.6 & 185.6 & 1.00 \\
\hline ACRG3 2 & 5.84 & -1.578 & 865.1 & 862.6 & 4.65 \\
\hline ACRG3 31 & 2.47 & -1.851 & 658.5 & 607.0 & 3.27 \\
\hline ACRG3 32 & Omitted * & -0.810 & $1,858.3$ & $1,858.3$ & 10.01 \\
\hline ACRG3 41 & 4.04 & -1.376 & $1,059.5$ & $1,041.2$ & 5.61 \\
\hline ACRG3 42 & 5.48 & -0.985 & $1,565.5$ & $1,559.0$ & 8.40 \\
\hline ACRG3 43 & Omitted * & -0.721 & $2,039.0$ & 2,039.0 & 10.99 \\
\hline ACRG3 44 & Omitted * & -0.360 & $2,924.7$ & $2,924.7$ & 15.76 \\
\hline ACRG3 51 & 3.34 & -1.191 & $1,274.4$ & $1,230.8$ & 6.63 \\
\hline ACRG3 52 & 4.42 & -0.703 & $2,076.8$ & $2,052.2$ & 11.06 \\
\hline ACRG3 53 & 4.66 & -0.387 & 2,847.1 & $2,820.4$ & 15.20 \\
\hline ACRG3 54 & 4.49 & -0.299 & $3,108.6$ & $3,074.2$ & 16.57 \\
\hline ACRG3 55 & 3.65 & -0.142 & $3,639.6$ & $3,547.6$ & 19.12 \\
\hline ACRG3 56 & Omitted * & 0.843 & $9,737.8$ & $9,737.8$ & 52.47 \\
\hline ACRG3 61 & 5.11 & -0.443 & $2,692.4$ & $2,676.2$ & 14.42 \\
\hline ACRG3 62 & 5.71 & -0.075 & $3,888.5$ & $3,875.6$ & 20.88 \\
\hline ACRG3 63 & 5.87 & 0.121 & $4,734.3$ & $4,721.0$ & 25.44 \\
\hline ACRG3 64 & Omitted * & 0.365 & $6,042.7$ & $6,042.7$ & 32.56 \\
\hline ACRG3 65 & Omitted * & 0.547 & $7,243.5$ & $7,243.5$ & 39.03 \\
\hline ACRG3 66 & Omitted * & 0.000 & 4,193.3 & 4,193.3 & 22.60 \\
\hline ACRG3 71 & Omitted * & 0.131 & $4,779.5$ & $4,779.5$ & 25.76 \\
\hline ACRG3 72 & 4.70 & 0.431 & $6,450.4$ & $6,392.4$ & 34.45 \\
\hline ACRG3 73 & Omitted * & 0.636 & $7,919.5$ & 7,919.5 & 42.68 \\
\hline ACRG3 74 & Omitted $*$ & 0.840 & $9,711.6$ & $9,711.6$ & 52.33 \\
\hline ACRG3 75 & Omitted * & 1.127 & $12,944.2$ & $12,944.2$ & 69.75 \\
\hline ACRG3 76 & Omitted * & 0.789 & $9,232.0$ & $9,232.0$ & 49.75 \\
\hline ACRG3 81 & 3.27 & 0.012 & $4,243.3$ & $4,088.4$ & 22.03 \\
\hline ACRG3 82 & 3.44 & 0.619 & $7,784.5$ & $7,541.9$ & 40.64 \\
\hline ACRG3 83 & 4.73 & 0.842 & $9,733.4$ & $9,648.5$ & 51.99 \\
\hline ACRG3 84 & 3.70 & 1.154 & $13,295.1$ & $12,975.5$ & 69.92 \\
\hline ACRG3 85 & Omitted * & 1.253 & $14,674.4$ & $14,674.4$ & 79.08 \\
\hline ACRG3 91 & 3.38 & -0.080 & $3,869.0$ & $3,741.9$ & 20.16 \\
\hline ACRG3 92 & Omitted * & 0.953 & $10,872.6$ & $10,872.6$ & 58.59 \\
\hline ACRG3 93 & Omitted $*$ & 2.061 & $32,943.0$ & $32,943.0$ & 177.52 \\
\hline ACRG3 94 & Omitted * & 1.687 & $22,648.7$ & $22,648.7$ & 122.05 \\
\hline ACRG3 95 & Omitted * & 2.260 & $40,190.5$ & $40,190.5$ & 216.58 \\
\hline ACRG3 96 & Omitted * & 2.655 & $59,627.0$ & $59,627.0$ & 321.32 \\
\hline
\end{tabular}

$\mathrm{P}(\mathrm{c}>0)=\frac{e^{\text {cons }+ \text { coefficent }(2)}}{1+e^{\text {cons }+ \text { coefficient }(2)}}$ 
Note Table 4:

(*omitted) Groups with positive cost values only $(P(c>0)=1)$

Column 2: Logit regression coefficients according to the equation [2].

Column 3: Log OLS regression coefficients according to the equation [3].

Column 4: Retransformed values of coefficients of column 3 multiplied by the smearing estimator.

Figure 1. Mean prediction of actual total healthcare cost of ACRG3 by decile

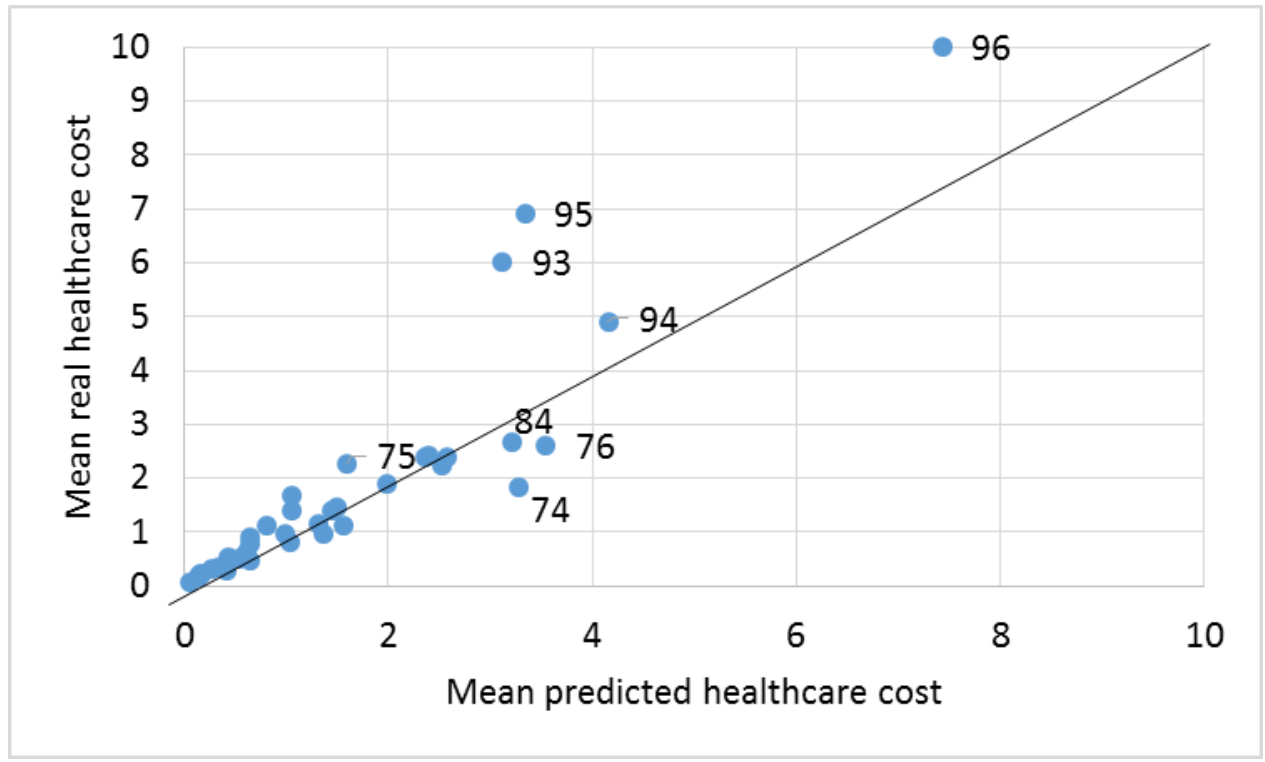

Note:

Each point refers to a multimorbidity group represented by two digits: the first digit is the MHS ( 1 to 9 ) and the second the severity level (1 to 6$)$. 
Figure 2. Case mix, population and adjusted patients for each health district in Valencian Community

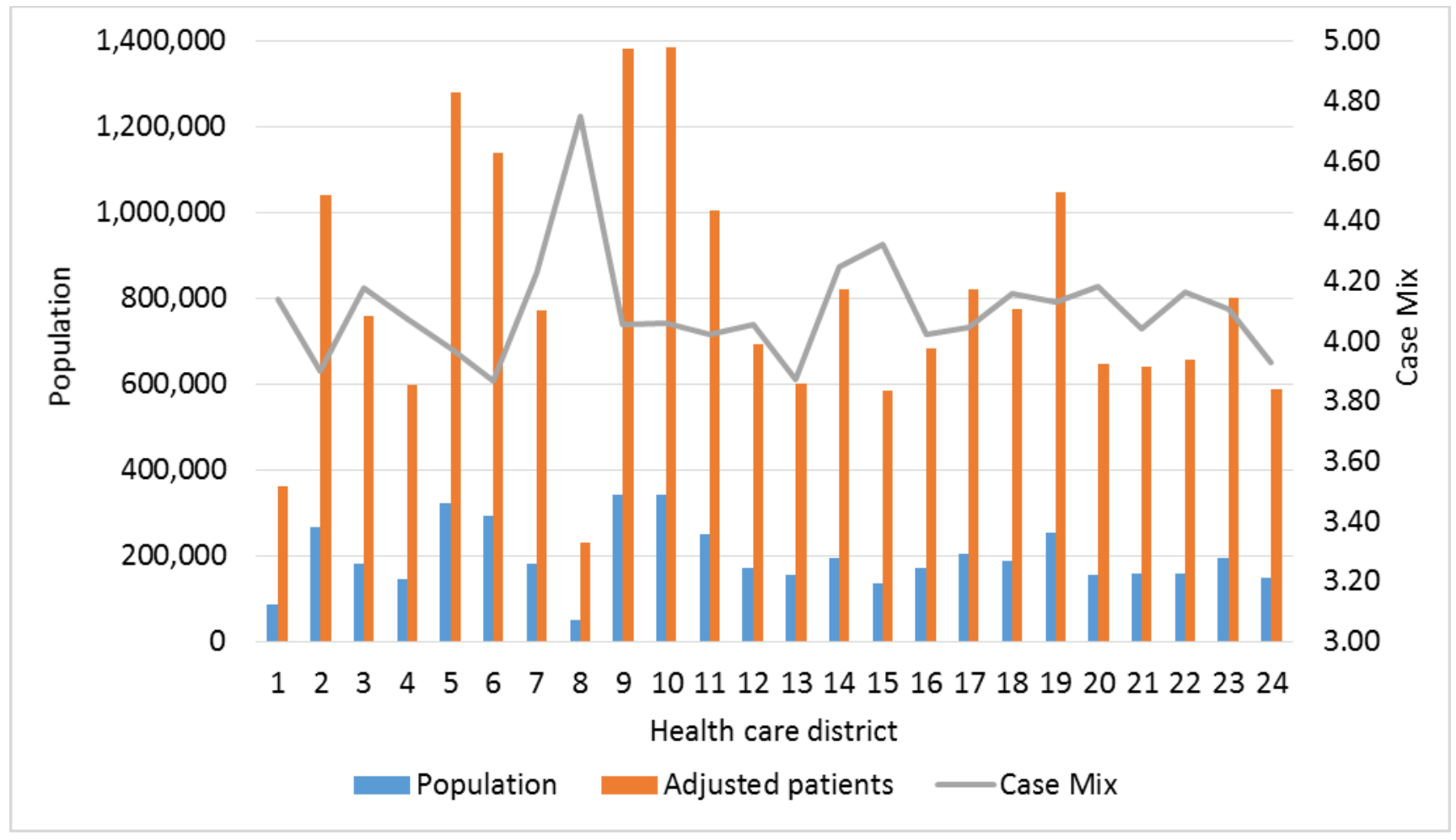

